\title{
Factors influencing oestrogen-induced sensitization to acetylcholine of guinea-pig uterine artery
}

\author{
C. Bell and Catherine Coffey \\ Department of Physiology, University of Melbourne Medical Centre, Parkville, Victoria 3052, \\ Australia
}

\begin{abstract}
Summary. The guinea-pig uterine artery responded to acetylcholine $(\mathrm{ACh})$ with vasodilatation only during pregnancy or after oestrogen treatment. Even with high doses $(1 \mathrm{mg} /$ day) oestradiol-17 $\beta$ esters had to be administered for several days to effect sensitization to $\mathrm{ACh}$, but oestradiol- $17 \beta$ itself was active within a few hours. Oestriol was equipotent with oestradiol. Sensitization was prevented when protein synthesis was inhibited over the period of oestrogen administration, but was not dependent on the integrity of the cholinergic vasodilator nerve supply to the artery.
\end{abstract}

\section{Introduction}

Oestrogens produce dilatation of the uterine vascular bed in a variety of species (Markee, 1940; Borell, Fernstrom \& Westman, 1953; Dickson, Bosc \& Locatelli, 1969; Greiss \& Anderson, 1970; see also Bell, 1974a), and this probably contributes to the progressive and sustained increase in uterine blood flow that occurs during pregnancy. In the guinea-pig, the uterine arterial vessels are innervated by cholinergic vasodilator nerves, but the arterial muscle is responsive to acetylcholine $(\mathrm{ACh})$ of neural or extrinsic origin only during the second half of pregnancy (Bell, 1968). This suggests that any physiological role for the dilator nerves would be one related to reduction of uterine vascular resistance during pregnancy. Responsiveness to $\mathrm{ACh}$ can be produced in uterine arteries from virgin animals by chronic administration of oestradiol-17ß (Bell, 1973). Therefore, the contribution of oestrogens to the uterine hyperaemia of pregnancy in guinea-pigs is likely to be mediated through effects on ACh receptors.

The present paper reports the results of some experiments carried out to investigate the mechanism of action of oestrogens on $\mathrm{ACh}$ responsiveness in the guinea-pig uterine artery.

\section{Materials and Methods}

Isolated parametrial arteries from adult (350-500 g) virgin guinea-pigs were perfused with saline $(9 \mathrm{~g} \mathrm{NaCl} / \mathrm{l})$ at $4 \mathrm{ml} \mathrm{min}{ }^{-1}$ as described previously (Bell, 1968), and dilator responsiveness to ACh was assessed. The procedure used for this has been described in detail by Bell (1973). Briefly, reproducible constrictor responses to intraluminal injection of noradrenaline $\left(5 \times 10^{-7} \mathrm{~g}\right)$ were obtained, following which the vessel tone was raised by infusion of $5 \times 10^{-7} \mathrm{~g}$ noradrenaline $/ \mathrm{ml}$ and the dilator effect of $\mathrm{ACh}\left(5 \times 10^{-8} \mathrm{~g}\right)$ was determined. Responsiveness to $\mathrm{ACh}$ was expressed as the ratio of the magnitude of responses to $\mathrm{ACh}$ and noradrenaline. When no response to ACh was obtained, glyceryl trinitrate $\left(5 \times 10^{-7}-5 \times 10^{-6} \mathrm{~g}\right)$ was injected to confirm that the vessel was capable of substantial dilatation. 
Oestrogen administration was by intramuscular injection in arachis oil. The compounds used were oestradiol-17 $\beta$ (Sigma, St Louis, Missouri), oestradiol-17 $\beta$ benzoate (Sigma), oestradiol$17 \beta$ valerate (Primogyn Depot: Schering, Tempe, New South Wales), oestradiol-17 $\beta$ dipropionate (Sigma) and oestriol triacetate (Sigma).

Unilateral cholinergic denervation of the parametrial arteries was performed surgically under anaesthesia as described by Bell (1974b). At least 4 days was allowed after operation for neural degeneration to occur before $\mathrm{ACh}$ responsiveness was assessed or oestrogen treatment was initiated. After perfusion, the efficacy of denervation was confirmed by the absence of a perivascular plexus of acetylcholinesterase-positive axons in the operated artery and its presence in the contralateral control vessel (Bell, 1974b).

\section{Results}

\section{Responsiveness to $A C h$}

As reported previously (Bell 1968, 1973), uterine arteries from virgin guinea-pigs, whether in oestrus or dioestrus, were virtually unresponsive to $\mathrm{ACh}$ even at doses as high as $1 \mathrm{mg}$. The ratio of amplitudes of responses to the standard challenge doses of $\mathrm{ACh}$ and noradrenaline varied from 0 (i.e. no response to $\mathrm{ACh}$ ) to $13 \%$ (Table 1).

Table 1. Sensitization to acetylcholine (ACh) of guinea-pig uterine arteries after treatment with various regimens of oestradiol or with oestriol

\begin{tabular}{|c|c|c|c|c|}
\hline \multirow[b]{2}{*}{ Treatment } & \multirow{2}{*}{$\begin{array}{l}\text { Duration } \\
\text { of } \\
\text { treatment }\end{array}$} & \multirow[b]{2}{*}{$\begin{array}{l}\text { No. of } \\
\text { animals }\end{array}$} & \multicolumn{2}{|l|}{ Responsiveness to $\mathrm{ACh}(\%)^{*}$} \\
\hline & & & Individual arteries & $\begin{array}{c}\text { Mean } \\
\pm \text { s.e.m. }\end{array}$ \\
\hline $\begin{array}{l}\text { None } \\
\text { Oestradiol-17 } \beta\end{array}$ & - & 9 & $0,0,0,0,0,0,0,0,0,3,3,7,7,13$ & $2 \pm 1 \cdot 0$ \\
\hline valerate $(1 \mathrm{mg} /$ day $)$ & $\begin{array}{r}5 \text { days } \\
7 \text { days } \\
14 \text { days }\end{array}$ & $\begin{array}{l}9 \\
4 \\
3\end{array}$ & $\begin{array}{l}0,0,0,9,9,11,12,16,18,72,95,102,142 \\
17,31,39,50 \\
0,12,14,18,43\end{array}$ & $\begin{array}{l}37 \pm 13 \ddagger \\
34 \pm 6 \cdot 9 \ddagger \\
17 \pm 7 \cdot 2 \ddagger\end{array}$ \\
\hline $\begin{array}{l}\text { Oestradiol-17 } \beta \text { benzoate } \\
\text { (1 mg/day) }\end{array}$ & 5 days & 6 & $0,0,9,9,13,14,33,40,40,50$ & $21 \pm 5.7 \ddagger$ \\
\hline 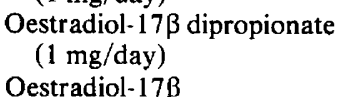 & 5 days & 6 & $0,0,0,0,0,0,0,0,0,12,17$ & $3 \pm 1 \cdot 8$ \\
\hline $1 \mathrm{mg}$ & $\begin{array}{r}6 \mathrm{~h} \\
24 \mathrm{~h}\end{array}$ & $\begin{array}{l}7 \\
6\end{array}$ & $\begin{array}{l}0,0,0,0,4,8,8,10,10,26,32 \\
0,0,6,6,13,16,18,39,56,140\end{array}$ & $\begin{aligned} 9 & \pm 3 \cdot 4 \dagger \\
29 & +14 \dagger\end{aligned}$ \\
\hline $\begin{array}{l}10 \mathrm{mg} \\
\text { Oestriol triacetate } \\
(1 \mathrm{mg} / \text { day })\end{array}$ & $\begin{array}{l}6 \mathrm{~h} \\
5 \text { days }\end{array}$ & $\begin{array}{l}8 \\
7\end{array}$ & $\begin{array}{l}0,0,5,6,8,10,10,19,20,29,35,52 \\
0,0,3,4,6,8,11,15,27,32,53\end{array}$ & $\begin{array}{l}16 \pm 4.5 \neq \\
14 \pm 5.0 \ddagger\end{array}$ \\
\hline
\end{tabular}

* Expressed as $\frac{\text { amplitude of response to } 5 \times 10^{-8} \mathrm{~g} \mathrm{ACh}}{\text { amplitude of response to } 5 \times 10^{-7} \mathrm{~g} \text { noradrenaline }} \times 100$.

Significantly different from untreated value by unpaired 2 -tailed $t$ test: $\dagger P<0.05 ; \ddagger P<0.02$.

\section{Effects of treatment with different oestradiol preparations}

Treatment with oestradiol- $17 \beta$ valerate $(1 \mathrm{mg} /$ day $)$ for 5 days produced a degree of responsiveness (Table 1) similar to that occurring during pregnancy $(32 \pm 7.0 \%$; Bell, 1973); increasing the period of treatment to 14 days produced no further effect. Oestradiol-17 $\beta$ benzoate produced a significant but smaller degree of sensitization when given at the same dosage for 5 days. By contrast, the dipropionate ester of oestradiol- $17 \beta$ was virtually without effect when used over the same period (Table 1). No sensitizing effect was seen in any of several 
animals 5 days after a single $1 \mathrm{mg}$ dose of the benzoate or valerate esters (data not shown). However, after a single dose of $1 \mathrm{mg}$ oestradiol-17 $\beta$ itself, some sensitization was present after 6 $h$, and by $24 \mathrm{~h}$ the effect was as great as seen with repeated administration of the valerate ester for 5 days. When $10 \mathrm{mg}$ oestradiol-17 $\beta$ were given, substantial sensitization was present within 6 h (Table 1).

\section{Comparison of oestriol and oestradiol}

Seven animals were treated with oestriol triacetate $(1 \mathrm{mg} /$ day) for 5 days. Arteries from these animals were sensitized to $\mathrm{ACh}$ in all but one animal. The effect of oestriol was quantitatively similar to that of a similar period of treatment with oestradiol-17 $\beta$ benzoate. Although the effect was rather less than that of oestradiol-17 $\beta$ valerate (Table 1), this difference was not significant $(P>0 \cdot 1)$. The effects of treatment with the different oestrogens for 5 days on the macroscopic appearance of the uterus were dramatically different. Oestriol had no obvious effect except for slight flushing. By contrast, the oestradiol-17 $\beta$ esters caused pronounced flushing and some uterine hypertrophy.

\section{Involvement of protein synthesis in the effect of oestrogen}

In 5 animals, the sensitizing effect of a 6 -h treatment with $10 \mathrm{mg}$ oestradiol-17 $\beta$ was examined during inhibition of protein synthesis with cycloheximide (Sigma), $10 \mathrm{mg} / \mathrm{kg}$ i.p., given $0.5 \mathrm{~h}$ before and $3 \mathrm{~h}$ after the oestradiol. In these animals, by contrast with those which received $10 \mathrm{mg}$ oestradiol- $17 \beta$ alone for the same period, no sensitization to $\mathrm{ACh}$ occurred, the mean response obtained from 9 arteries being $1 \pm 0.8 \%$. Because of the toxic effects of cycloheximide the effects of longer periods of oestrogen treatment in the absence of protein synthesis could not be studied.

\section{Effects of cholinergic denervation}

By 9 days after unilateral section of the cholinergic nerves supplying the uterine artery in 4 animals, there was no response to $\mathrm{ACh}$ in control or denervated arteries (controls: $0,0,0,6 \%$; contralateral denervated: $0,0,0,4 \%$ ). In a further 7 animals, several days after unilateral denervation, oestradiol- $17 \beta$ valerate was administered at $1 \mathrm{mg} / \mathrm{day}$ for 7 days. In every animal, sensitization to $\mathrm{ACh}$ occurred in both arteries, although the degree of sensitization obtained in all but one animal was greater in the control artery (controls: 17, 31, 39, 43, 65, 70\%, mean 36 $\pm 9 \%$; equivalent denervated: $6,13,48,10,20,50 \%$, mean $20 \pm 7 \%$ ).

\section{Discussion}

In the initial study of oestrogen-induced responsiveness to ACh of the uterine artery, a striking feature was the need for prolonged treatment with massive doses of hormone (Bell, 1973). The present results suggest at least partial explanations for these requirements. While each of the oestradiol-17 $\beta$ esters tested had to be administered for several consecutive days in order to produce an effect, a single dose of similar size of oestradiol-17 $\beta$ itself was effective within 6-24 $\mathrm{h}$. This indicates that the latency of action of the esters is dictated by the low bioavailability of the hormone molecule itself. It is probable that sensitization occurs in considerably less than $6 \mathrm{~h}$ once the hormone is present in the bloodstream. Sensitization to $\mathrm{ACh}$ in a proportion of animals $1 \mathrm{~h}$ after intramuscular administration of $10 \mathrm{mg}$ oestradiol-17 $\beta$ has been observed (C. Coffey, unpublished observation). In the sheep the uterine dilator effect of oestrogens appears within 30-40 min after intra-arterial administration (Killam, Rosenfeid, Battaglia, Makowski \& 
Meschia, 1973), although ACh receptors do not appear to be involved in this species (Nuwayhid, Brinkman, Woods, Martinek \& Assali, 1975).

Even using the parent hormone oestradiol-17 $\beta$ rather than one of its esters, rapid sensitization to $\mathrm{ACh}$ required extremely large doses of hormone, relative to the estimated figure of $2.6 \mu \mathrm{g} /$ day for oestrogen production during pregnancy in the guinea-pig (Challis, Heap \& Illingworth, 1971). It has been suggested previously that this could be due to mediation of the sensitizing effect by an oestrogen other than oestradiol-17 $\beta$ (Bell, 1973). Hechter \& Halkerston (1964) drew attention to the fact that, while oestradiol- $17 \beta$ is by far the most potent oestrogen in terms of uterotrophic activity, it is almost matched by oestriol in potency with regard to induction of uterine hyperaemia and water imbibition. In the sheep uterine artery the dilator potencies of oestradiol-17ß and oestriol are similar (Resnik, Killam, Battaglia, Makowski \& Meschia, 1974). It is therefore of interest that in our experiments, oestriol was as effective as oestradiol- $17 \beta$ in sensitizing the muscle to $\mathrm{ACh}$, while having no obvious uterotrophic effect even at the large dosage used. It is tempting to suggest that oestriol rather than oestradiol mediates the sensitization to $\mathrm{ACh}$ which occurs during pregnancy. The low potency of exogenous oestradiol may reflect its metabolic fate: only a very small proportion of administered oestradiol-17 $\beta$ appears to be converted to oestriol in guinea-pigs, most being converted to oestrone (Stoa \& Borjesson, 1971).

Inhibition of protein synthesis with cycloheximide prevented the sensitizing effect of oestrogen. It is however still uncertain whether the protein affected represents new ACh receptors or some other component of the cell. In a considerable proportion of arteries from non-pregnant guinea-pigs, in the absence of oestrogen priming, an initial challenge with $\mathrm{ACh}$ produces dilatation but all subsequent doses are ineffective (Bell, 1968). This could be interpreted as evidence that the ACh receptors necessary for dilatation are already present in non-sensitized animals, and that the obligatory protein synthesis during sensitization involves molecules which control receptor function rather than their existence per se. On the other hand, in the hypothalamus, oestrogen treatment has been reported to increase the number of neuronal ACh receptors, as measured by ligand binding (Rainbow, Degroff, Luine \& McEwan, 1980). In either case, it is unlikely that the requirement for protein synthesis merely reflects a generalized arterial hypertrophy in the presence of oestrogen, with consequent proliferation of all membrane components. Although during pregnancy the uterine arterial dimensions increase considerably (see Moll \& Espach, 1981), the periods of exogenous oestrogen treatment which we have used are insufficient to produce appreciable structural changes; 5 days of treatment with oestradiol- $17 \beta$ benzoate $(1 \mathrm{mg} /$ day) was not associated with any change in wet or dry weights of arteries from a series of 12 animals, when compared to a body weight-matched control group (C. Bell, unpublished observation).

It is well known that nerves can exert transynaptic control over various properties of innervated effector cells, including the number of receptors for the relevant neurotransmitter (see Grampp, Harris \& Thesleff, 1972; Harris, 1974; Hughes \& Carr, 1978). In smooth as in skeletal muscle, chronic interruption of cholinergic neural activity results in increased numbers of active muscle membrane ACh receptors (Sachs, Kloog, Korczyn, Heron \& Sokolovsky, 1979), indicating that normally the nerve inhibits production of receptors or their functional expression. As the guinea-pig uterine artery receives a cholinergic nerve supply, some transynaptic process might be involved in the enhancement of $\mathrm{ACh}$ responsiveness produced by oestrogens. However the present results do not support this. Chronic surgical denervation of the vessel did not itself induce responsiveness, indicating that the normal insensitivity to $\mathrm{ACh}$ is not due to a neuronal influence. Furthermore, denervation did not prevent the sensitizing effect of subsequent oestrogen treatment. Therefore, the action of oestrogens appears to be exerted on the muscle cell directly. Nevertheless, as activation of $\mathrm{ACh}$ receptors in vivo is unlikely to occur through $\mathrm{ACh}$ from extraneuronal sources, any physiological role for the oestrogen-induced responsiveness is almost certainly dependent on neural activity. 
This work was supported by the National Heart Foundation of Australia. We thank Karen Mather for technical assistance, and Schering Pty Ltd, Tempe, New South Wales, for a gift of Primogyn Depot.

\section{References}

Bell, C. (1968) Dual vasoconstrictor and vasodilator innervation of the uterine arterial supply in the guinea-pig. Circ. Res. 23, 279-289.

Bell, C. (1973) Oestrogen-induced sensitization of the uterine artery of the guinea-pig to acetylcholine. $B r$. J. Pharmac. 49, 595-601.

Bell, C. (1974a) Control of uterine blood flow in pregnancy. Med. Biol. 52, 219-228.

Bell, C. (1974b) Selective cholinergic denervation of the uterine artery in the guinea-pig. Experientia 30, 257-258.

Borell, U., Fernstrom, I. \& Westman, A. (1953) Hormonal influence in the uterine arteries: an arteriographic study in the human. Acta obstet. gynec. scand. 32, 271-284.

Challis, J.R.G., Heap, R.B. \& Illingworth, D.V. (1971) Concentrations of oestrogen and progesterone in the plasma of non-pregnant, pregnant and lactating guinea-pigs. J. Endocr. 51, 333-345.

Dickson, W.M., Bosc, M.J. \& Locatelli, A. (1969) Effect of oestrogen and progesterone on uterine blood flow of castrate sows. Am. J. Physiol. 217, 14311434.

Grampp, W., Harris, J.B. \& Thesleff, S. (1972) Inhibition of denervation charges in skeletal muscle by blockers of protein synthesis. J. Physiol., Lond. 221, 743-754.

Greiss, F.C., Jr \& Anderson, S.G. (1970) Effect of ovarian hormones on the uterine vascular bed. Am.J. Obstet. Gynec. 107, 829-836.

Harris, A.J. (1974) Inductive functions of the nervous system. Ann. Rev. Physiol. 36, 251-305.

Hechter, O. \& Halkerston, I.D.K. (1964) On the action of mammalian hormones. In The Hormones, Vol. V, pp. 697-826. Eds G. Pincus, K. V. Thimann \& E. B. Astwood. Academic Press, New York.
Hughes, A.F. \& Carr, V.McM. (1978) The interaction of periphery and center in the development of dorsal root ganglia. In Handbook of Sensory Physiology, Vol. IX, pp. 85-114. Ed. M. Jacobson. Springer Verlag, Berlin.

Killam, A.P., Rosenfeld, C.R., Battaglia, F.C., Makowski, E.L. \& Meschia, G. (1973) Effect of estrogens on the uterine blood flow of oophorectomized ewes. Am. J. Obstet. Gynec. 115, 10451052.

Markee, J.E. (1940) Menstruation in intraocular endometrial transplants in the Rhesus monkey. Contrib. Embryol. Carn. Instn 28, 219-308.

Moll, W. \& Espach, A. (1981) Growth of uteroplacental arteries during pregnancy in the guinea-pig. Pflügers Arch. ges. Physiol. 389 (Suppl.), R15, Abstr.

Nuwayhid, B., Brinkman, C.R., Woods, J.R., Martinek, H. \& Assali, N.S. (1975) Effects of estrogens on systemic and regional circulations in normal and renal hypertensive sheep. Am. J. Obstet. Gynec. 123, 495-504.

Rainbow, T.C., Degroff, V., Luine, V.N. \& McEwan, B.S. (1980) Estradiol-17 $\beta$ increases the number of muscarinic receptors in hypothalamic nuclei. Brain Res. 198, 239-243.

Resnik, R., Killam, A.P., Battaglia, F.C., Makowski, E.L. \& Meschia, G. (1974) The stimulation of uterine blood flow by various estrogens. Endocrinology 94, 1192-1196.

Sachs, D.I., Kloog, Y., Korczyn, A.D., Heron, D.S. \& Sokolovsky, M. (1979) Denervation, supersensitivity and muscarinic receptors in the cat iris. Biochem. Pharmac. 28, 1513-1518.

Stoa, K.F. \& Borjesson, B.W. (1971) Metabolism of oestradiol-17 $\beta$ in the guinea pig. Biochim. Biophys. Acta 239, 337-344.

Received 10 November 1981 